\title{
Predictive factors of in hospital major adverse cardiac events and no reflow phenomenon in patients with ST elevation myocardial infarction undergoing primary percutaneous coronary intervention
}

Sherif Wagdy Ayad*, Mohamed Sobhy, Amr Zaki, and Amr Elkammash

Department of Cardiology, Faculty of Medicine, Alexandria University, Egypt

\begin{abstract}
Objectives: The study is designed to determine the relation between various clinical and laboratory variables and the occurrence of no reflow phenomenon or in hospital MACE (Cardiac death, myocardial infarction, stent thrombosis, or target vessel revascularization) in patients with STEMI undergoing primary PCI.

Background: The investigation of no-reflow phenomenon after primary percutaneous coronary intervention (PPCI) in patients with acute ST-segment-elevation myocardial infarction (STEMI) has therapeutic implications. Patients with no-reflow have more congestive heart failure early after myocardial infarction and demonstrate progressive left ventricular cavity dilatation in the convalescent stage of the infarction.

Methods: We studied prospectively 120 patients with STEMI presenting to Alexandria Main University Hospital (under umbrella of Stent for Life program) and International Cardiac Center (ICC) from April 2013 to October 2013, and eligible for PPCI according to European Society of Cardiology (ESC) guidelines.

Results: The incidence of no reflow was $13.2 \%$, and in hospital MACE was 5\%, with cardiac death as the predominant form of in hospital MACE. The group with no reflow and/or in hospital MACE showed significantly older age $(62.29 \pm 7.90$ vs. $56.30 \pm 10.34$, p=0.014), longer pain to balloon time (15.90 \pm 7.87 vs. $6.08 \pm$ 3.82, $\mathrm{p}<0.001)$, higher levels of admission random plasma glucose (RPG), neutrophils/lymphocytes $(\mathrm{N} / \mathrm{L})$ ratio $(8.19 \pm 3.05 v s .5 .44 \pm 3.53$, $\mathrm{p}<0.001)$, and $\mathrm{MPV}$ $(11.90 \pm 2.09$ vs. $8.58 \pm 1.84, \mathrm{p}<0.001)$.

Conclusion: Older patient age, longer pain to balloon time, admission hyperglycemia, higher admission N/L ratio and MPV are useful predictive factors for the occurrence of no reflow post PPCI, and/or in hospital MACE. Therefore strong attention should be paid to patients with one or more of these predictive factors, to protect them from the deleterious effects of no reflow, and avoid any of the in hospital MACE.
\end{abstract}

\section{Introduction}

The phenomenon of no-reflow is defined as inadequate myocardial perfusion through a given segment of the coronary circulation without angiographic evidence of mechanical vessel obstruction [1]. Noreflow has been documented in $30 \%$ of patients after thrombolysis or mechanical intervention for acute myocardial infarction [2]. No reflow implies abnormal tissue perfusion and persistent no-reflow is associated with higher incidence of congestive heart failure early after myocardial infarction and demonstrate progressive left ventricular cavity dilatation in the convalescent stage of the infarction [3].

Several key patho-physiological processes, usually in combination, are believed to be responsible for this phenomenon, including distal embolization of atherothrombotic debris, thrombus formation, and endothelial dysfunction of the distal arteriolar and capillary bed, including endothelial desquamation and microcirculatory vasospasm.

\section{Aim of the work}

The study is designed to determine the relation between various clinical and laboratory variables and the occurrence of no reflow phenomenon or in hospital MACE (Cardiac death, myocardial infarction, stent thrombosis, or target vessel revascularization) in patients with STEMI undergoing primary PCI.

\section{Methods}

The study was conducted on 120 patients with STEMI presenting to Alexandria Main University Hospital (under umbrella of Stent For Life program) and International Cardiac Center (ICC) from April 2013 to October 2013, and eligible for PPCI according to European Society of Cardiology (ESC) guidelines. Informed consent taken from patients. Thorough history taking with special emphasis on risk factors (Age, gender, diabetes, hypertension, smoking, dyslipidemia, family history), history of acute coronary syndromes (ACS) and revascularization, Pain to balloon time, and the presence of pre-infarction angina. Complete clinical examination was done. Admission laboratory investigation

Correspondence to: Sherif Wagdy Ayad, Department of Cardiology, Faculty of Medicine, Alexandria University, Egypt, E-mail: sherifwagdyayad@yahoo.com

Keywords: mortality, myocardial infarction, no reflow, percutaneous coronary intervention, reperfusion

Received: May 23, 2015; Accepted: July 24, 2015; Published: July 27, 2015 
Ayad SW (2015) Predictive factors of in hospital major adverse cardiac events and no reflow phenomenon in patients with ST elevation myocardial infarction undergoing primary percutaneous coronary intervention

included: Complete blood count (CBC) (including mean platelet volume [MPV] and neutrophils/lymphocytes ratio), and random plasma glucose level. All patients had 12 lead electrocardiogram (ECG). The results of the coronary angiography indicating the infarct related artery (IRA), initial TIMI flow in the IRA, and the type of stent used in the PPCI were recorded. The patients were studied according to the presence of various clinical and laboratory variables (age, gender, absence of pre-infarction angina, pain to balloon time, location of the infarction, admission random plasma glucose level and $\mathrm{CBC}$ including neutrophils/lymphocytes ratio and MPV, and initial TIMI flow in the IRA), the final TIMI flow after the primary PCI, and the incidence of in hospital MACE [4].

\section{Results}

The patients are divided into two groups according to the final TIMI flow after the primary PCI, and the incidence of in hospital MACE as follows: Group A: had a normal flow after the $1^{\text {ry }}$ PCI and did not have In hospital MACE. Group B: had either no reflow after the $1^{\text {ry }}$ PCI or experienced In hospital MACE.

The distribution of the studied groups is shown in Table 1.

Table 1. Distribution of the studied groups.

\begin{tabular}{|l|c|c|}
\hline & No & $\mathbf{\%}$ \\
\hline Normal (group A) & 99 & 82.5 \\
\hline No reflow or hospital MACE (group B) & 21 & 17.5 \\
\hline No reflow only & 15 & 71.4 \\
\hline In hospital MACE only ( all in the form of cardiac death) & 5 & 23.8 \\
\hline Both & 1 & 4.8 \\
\hline
\end{tabular}

The demographic data of the two studied groups are shown in table 2 .

Table 2. Comparison between the two studied groups according to demographic data.

\begin{tabular}{|c|c|c|c|c|c|c|}
\hline & \multicolumn{2}{|c|}{ Group A $(n=99)$} & \multicolumn{2}{|c|}{ Group B $(n=21)$} & \multirow{2}{*}{$\begin{array}{c}\text { Test of } \\
\text { sig. }\end{array}$} & \multirow[t]{2}{*}{$\mathbf{p}$} \\
\hline & No & $\%$ & No & $\%$ & & \\
\hline \multicolumn{7}{|l|}{ Sex } \\
\hline Male & 75 & 75.8 & 13 & 61.9 & \multirow{2}{*}{$\chi^{2}=1.700$} & \multirow[t]{2}{*}{0.192} \\
\hline Female & 24 & 24.2 & 8 & 38.1 & & \\
\hline \multicolumn{7}{|l|}{ Age } \\
\hline Min. - Max. & \multicolumn{2}{|c|}{$29.0-81.0$} & \multicolumn{2}{|c|}{$44.0-78.0$} & \multirow[t]{3}{*}{$\mathrm{t}=2.498$} & \multirow[t]{3}{*}{0.014} \\
\hline Mean \pm SD & \multicolumn{2}{|c|}{$56.30 \pm 10.34$} & \multicolumn{2}{|c|}{$62.29 \pm 7.90$} & & \\
\hline Median & \multicolumn{2}{|c|}{58.0} & \multicolumn{2}{|c|}{62.0} & & \\
\hline
\end{tabular}

The distribution of the studied groups with respect to pre PPCI variable is shown in tables 3-6.

Table 3. Comparison between the two studied groups according to diabetes, hypertension and smoking.

\begin{tabular}{|c|c|c|c|c|c|c|}
\hline & \multicolumn{2}{|c|}{ Group A (n=99) } & \multicolumn{2}{|c|}{ Group B (n=21) } & \multirow[t]{2}{*}{$\chi^{2}$} & \multirow[t]{2}{*}{$\mathbf{p}$} \\
\hline & No & $\%$ & No & $\%$ & & \\
\hline \multicolumn{7}{|l|}{ Diabetes } \\
\hline Non diabetic & 62 & 62.6 & 9 & 42.9 & \multirow[t]{2}{*}{2.803} & \multirow[t]{2}{*}{${ }^{\mathrm{MC}} \mathrm{p}=0.094$} \\
\hline Diabetic & 37 & 37.4 & 12 & 57.1 & & \\
\hline Insulin & 9 & 9.1 & 2 & 9.5 & \multirow[t]{2}{*}{-} & \multirow[t]{2}{*}{ - } \\
\hline OHD & 28 & 28.3 & 10 & 47.6 & & \\
\hline Hypertension & 48 & 48.5 & 7 & 33.3 & 1.602 & 0.206 \\
\hline \multicolumn{7}{|l|}{ Smoking } \\
\hline Non smoker & 43 & 43.4 & 11 & 52.4 & 0.560 & 0.454 \\
\hline Smoker & 52 & 52.5 & 9 & 42.9 & 0.648 & 0.421 \\
\hline Ex-smoker & 4 & 4.0 & 1 & 4.8 & 0.023 & ${ }^{\mathrm{FE}} \mathrm{p}=1.000$ \\
\hline Dyslipidemia & 54 & & 15 & 71.4 & 2.021 & 0.155 \\
\hline Family History & 17 & & 2 & 9.5 & 0.760 & ${ }^{\mathrm{FE}} \mathrm{p}=0.521$ \\
\hline Previous ACS & 19 & & 3 & 14.3 & 0.279 & ${ }^{\mathrm{FE}} \mathrm{p}=0.762$ \\
\hline Absence of preinfarction angina & 56 & & 15 & 71.4 & 1.584 & 0.208 \\
\hline
\end{tabular}

Table 4. Comparison between the two studied groups according to SBP, DBP and pulse.

\begin{tabular}{|c|c|c|c|c|}
\hline & Group A $(n=99)$ & Group B $(n=21)$ & $\mathbf{t}$ & $\mathbf{p}$ \\
\hline \multicolumn{5}{|l|}{ SBP } \\
\hline Min. - Max. & $50.0-200.0$ & $70.0-160.0$ & \multirow[t]{3}{*}{1.971} & \multirow[t]{3}{*}{0.051} \\
\hline Mean \pm SD & $129.29 \pm 27.93$ & $116.67 \pm 19.32$ & & \\
\hline Median & 130.0 & 120.0 & & \\
\hline \multicolumn{5}{|l|}{ DBP } \\
\hline Min. - Max. & $30.0-120.0$ & $40.0-90.0$ & \multirow[t]{3}{*}{1.870} & \multirow[t]{3}{*}{0.064} \\
\hline Mean \pm SD & $81.06 \pm 15.62$ & $74.29 \pm 12.07$ & & \\
\hline Median & 80.0 & 70.0 & & \\
\hline \multicolumn{5}{|l|}{ Pulse } \\
\hline Min. - Max. & $41.0-120.0$ & $60.0-130.0$ & \multirow[t]{3}{*}{0.069} & \multirow[t]{3}{*}{0.945} \\
\hline Mean \pm SD & $84.56 \pm 16.33$ & $84.29 \pm 15.69$ & & \\
\hline Median & 80.0 & 88.0 & & \\
\hline
\end{tabular}

Table 5. Comparison between the two studied groups according to ECG.

\begin{tabular}{|c|c|c|c|c|c|c|}
\hline \multirow{2}{*}{} & \multicolumn{2}{|c|}{$\begin{array}{c}\text { Group A } \\
(\mathbf{n}=\mathbf{9 9})\end{array}$} & \multicolumn{2}{c|}{$\begin{array}{c}\text { Group B } \\
(\mathbf{n}=\mathbf{2 1})\end{array}$} & \multirow{2}{*}{$\chi^{\mathbf{2}}$} & \multirow{2}{*}{} \\
\cline { 2 - 6 } ECG & No & $\mathbf{9}$ & $\mathbf{N o}$ & $\mathbf{\%}$ & & \\
\hline Anterior MI & 72 & 72.7 & 14 & 66.7 & 0.313 & 0.576 \\
\hline Lateral MI & 6 & 6.1 & 2 & 9.5 & 0.334 & ${ }^{\mathrm{FE}} \mathrm{p}=0.628$ \\
\hline Inferior MI & 21 & 21.2 & 6 & 28.6 & 0.538 & ${ }^{\mathrm{FE}} \mathrm{p}=0.565$ \\
\hline Right MI & 8 & 8.1 & 1 & 4.8 & 0.275 & ${ }^{\mathrm{FE}} \mathrm{p}=1.000$ \\
\hline Posterior MI & 7 & 7.1 & 2 & 9.5 & 0.150 & ${ }^{\mathrm{FE}} \mathrm{p}=0.656$ \\
\hline
\end{tabular}

Table 6. Comparison between the two studied groups according to pain to balloon time.

\begin{tabular}{|c|c|c|c|c|}
\hline & $\begin{array}{c}\text { Group A } \\
(\mathbf{n = 9 9 )}\end{array}$ & $\begin{array}{c}\text { Group B } \\
(\mathbf{n = 2 1 )}\end{array}$ & $\mathbf{Z}$ & $\mathbf{p}$ \\
\hline Pain to balloon time & & & & \\
\hline Min. - Max. & $1.0-19.0$ & $1.0-30.0$ & \multirow{2}{*}{$4.999^{*}$} & $<0.001^{*}$ \\
\hline Mean \pm SD & $6.08 \pm 3.82$ & $15.90 \pm 7.87$ & & \\
\hline Median & 5.0 & 17.0 & & \\
\hline
\end{tabular}

The distribution of the studied groups with respect to laboratory results, angiographic findings and procedural aspects is shown in tables 7-9.

Table 7. Comparison between the two studied groups according to laboratory results (on admission).

\begin{tabular}{|c|c|c|c|c|}
\hline & $\begin{array}{c}\text { Group A } \\
(n=99)\end{array}$ & $\begin{array}{c}\text { Group B } \\
(\mathrm{n}=\mathbf{2 1})\end{array}$ & Test of sig. & p \\
\hline \multicolumn{5}{|l|}{ Plasma glucose } \\
\hline Min. - Max. & $84.0-442.0$ & $104.0-440.0$ & \multirow[t]{3}{*}{$\mathrm{Z}=3.377^{*}$} & \multirow[t]{3}{*}{$0.001^{*}$} \\
\hline Mean \pm SD & $186.38 \pm 84.65$ & $275.29 \pm 104.11$ & & \\
\hline Median & 150.0 & 280.0 & & \\
\hline \multicolumn{5}{|l|}{$\mathrm{N} / \mathrm{L}$ ratio } \\
\hline Min. - Max. & $1.20-24.0$ & $2.80-13.0$ & \multirow[t]{3}{*}{$Z=3.665$} & \multirow[t]{3}{*}{$<0.001^{*}$} \\
\hline Mean \pm SD & $5.44 \pm 3.53$ & $8.19 \pm 3.05$ & & \\
\hline Median & 4.50 & 8.0 & & \\
\hline \multicolumn{5}{|l|}{ MPV } \\
\hline Min. - Max. & $5.0-13.0$ & $5.90-15.0$ & \multirow[t]{3}{*}{$\mathrm{t}=7.320^{*}$} & \multirow[t]{3}{*}{$<0.001^{*}$} \\
\hline Mean \pm SD & $8.58 \pm 1.84$ & $11.90 \pm 2.09$ & & \\
\hline Median & 8.20 & 12.20 & & \\
\hline
\end{tabular}

\section{Discussion}

A lot of researchers tried to study variables predicting the incidence of no reflow and/or in hospital MACE in STEMI patients undergoing PPCI. Ndrepepa G et al. [5], found that initial TIMI 0 flow in the infarct-related artery $(P<0.001)$, initial perfusion defect $(P<0.03)$, and previous myocardial infarction $(P<0.013)$ as independent predictors of no reflow. Akpek $\mathrm{M}$ et al. [6], reported that $\mathrm{N} / \mathrm{L}$ ratio $>3.3$ predicted no 
Ayad SW (2015) Predictive factors of in hospital major adverse cardiac events and no reflow phenomenon in patients with ST elevation myocardial infarction undergoing primary percutaneous coronary intervention

Table 8. Comparison between the two studied groups according to infarct related artery.

\begin{tabular}{|c|c|c|c|c|c|c|}
\hline \multirow{2}{*}{} & \multicolumn{2}{|c|}{$\begin{array}{c}\text { Group A } \\
\text { (n=99) }\end{array}$} & \multicolumn{2}{c|}{$\begin{array}{c}\text { Group B } \\
\text { (n=21) }\end{array}$} & \multirow{2}{*}{$\chi^{\mathbf{2}}$} & \multirow{2}{*}{$\mathbf{p}$} \\
\cline { 2 - 6 } & $\mathbf{N o}$ & $\mathbf{\%}$ & $\mathbf{N o}$ & $\mathbf{\%}$ & & \\
\hline Infarct related artery & & & & & & \multirow{2}{*}{} \\
\cline { 1 - 6 } LAD & 70 & 70.7 & 14 & 66.7 & 0.135 & 0.714 \\
\hline D1 & 5 & 5.1 & 0 & 0.0 & - & - \\
\hline CX & 2 & 2.0 & 2 & 9.5 & 3.027 & ${ }^{\mathrm{FE}} \mathrm{p}=0.141$ \\
\hline OM & 1 & 1.0 & 0 & 0.0 & - & - \\
\hline RCA & 20 & 20.2 & 5 & 23.8 & 0.137 & ${ }^{\mathrm{FE}} \mathrm{p}=0.769$ \\
\hline PDA & 1 & 1.0 & 0 & 0.0 & 0.214 & ${ }^{\mathrm{FE}} \mathrm{p}=1.000$ \\
\hline
\end{tabular}

Table 9. Comparison between the two studied groups according to initial TIMI flow and Type of stent used.

\begin{tabular}{|c|c|c|c|c|c|c|}
\hline \multirow{2}{*}{} & \multicolumn{2}{|c|}{$\begin{array}{c}\text { Group A } \\
(\mathbf{n = 9 9 )}\end{array}$} & \multicolumn{2}{c|}{$\begin{array}{c}\text { Group B } \\
(\mathbf{n = 2 1}\end{array}$} & \multirow{2}{*}{ Test of sig. } & \multirow{2}{*}{ p } \\
\cline { 1 - 5 } & No & $\mathbf{\%}$ & No & $\mathbf{\%}$ & & \\
\hline Initial TIMI flow & & & & & & \\
\hline 0 & 87 & 87.6 & 19 & 90.4 & $\mathrm{Z}=1.844$ & \multirow{2}{*}{0.065} \\
\hline 1 & 25 & 25.3 & 1 & 4.8 & & \\
\hline 2 & 5 & 5.1 & 1 & 4.8 & & \\
\hline Type of stent used & & & & & & \\
\hline No stent & 0 & 0.0 & 2 & 9.5 & $\chi^{2}=9.588^{*}$ & ${ }^{\mathrm{FE}} \mathrm{p}=0.029^{*}$ \\
\hline BMS & 51 & 51.5 & 12 & 57.1 & $\chi^{2}=0.220$ & 0.810 \\
\hline DES & 48 & 48.5 & 7 & 33.3 & $\chi^{2}=1.602$ & 0.236 \\
\hline
\end{tabular}

reflow with $74 \%$ sensitivity, and $83 \%$ specificity, and that high $\mathrm{N} / \mathrm{L}$ ratio is independent predictor of no reflow, and in hospital MACE. Iwakura $\mathrm{K}$ et al. [7], found that admission hyperglycemia (>160 mg/dl) was an independent prognostic factor for no reflow, along with older age, male gender, absence of pre-infarction angina, complete occlusion of the culprit lesion, and anterior STEMI. Huczek Z et al. [8], found that high mean platelet volume $(>10.3 \mathrm{fl})$ is a strong, independent predictor of no reflow in STEMI patients undergoing PPCI. In our study, we found that the groups with no reflow or in hospital MACE showed significantly older age, longer pain to balloon time, and higher levels of admission random plasma glucose (RPG), N/L ratio, and MPV.

\section{Conclusion}

Older patient age, longer pain to balloon time, admission hyperglycemia, higher admission N/L ratio and MPV are useful predictive factors for the occurrence of no reflow post PPCI, and/or in hospital MACE. Therefore strong attention should be paid to patients with one or more of these predictive factors, to protect them from the deleterious effects of no reflow, and avoid any of the in hospital MACE.

\section{References}

1. Morishima I, Sone T, Okumura K, Tsuboi H, Kondo J, et al. (2000) Angiographic noreflow phenomenon as a predictor of adverse long-term outcome in patients treated with percutaneous transluminal coronary angioplasty for first acute myocardial infarction. $J$ Am Coll Cardiol 36: 1202-1209. [Crossref]

2. Abbo KM, Dooris M, Glazier S, O’Neill WW, Byrd D, et al. (1995) Features and outcome of no-reflow after percutaneous coronary intervention. Am J Cardiol 75: 778782. [Crossref]

3. Bonz AW, Lengenfelder B, Strotmann J, Held S, Turschner O, et al. (2002) Effect of additional temporary glycoprotein IIb/IIIa receptor inhibition on troponin release in elective percutaneous coronary interventions after pretreatment with aspirin and clopidogrel (TOPSTAR trial). J Am Coll Cardiol 40: 662-668. [Crossref]

4. Rezkella SH, Kloner RA (2002) No-reflow phenomenon. Circulation 105: 656-662. [Crossref]

5. Ndrepepa G, Tiroch K, Keta D, Fusaro M, Seyfarth M, et al. (2010) Predictive Factors and Impact of No Reflow After Primary Percutaneous Coronary Intervention in Patients With Acute Myocardial Infarction. Circ Cardiovasc Interv 3: 27-33. [Crossref]

6. Akpek M, Sahin O, Elick D, Kaya MG (2013) The association of neutrophils/ lymphocytes ratio with coronary flow and in hospital MACE in patients with STEMI undergoing primary PCI. Eur Heart $J$ 27: 534-539.

7. Iwakura K, Ito H, Ikushima M, Kawano S, Okamura A, et al. (2003) Association between hyperglycemia and the no-reflow phenomenon in patients with acute myocardial infarction. J Am Coll Cardiol 41: 1-7. [Crossref]

8. Huczek Z, Kochman J, Filipiak KJ, Horszczaruk GJ, Grabowski M, et al. (2005) Mean platelet volume on admission predicts impaired reperfusion and long-term mortality in acute myocardial infarction treated with primary percutaneous coronary intervention. $J$ Am Coll Cardiol 46: 284-290. [Crossref]

Copyright: $@ 2015$ Ayad SW. This is an open-access article distributed under the terms of the Creative Commons Attribution License, which permits unrestricted use, distribution, and reproduction in any medium, provided the original author and source are credited. 